\title{
Integration of the ecosystem services concept in planning documents from six municipalities in southwestern Sweden
}

\author{
Amanda C. Nordin $^{1}$, Helena I. Hanson ${ }^{1}$ and Johanna Alkan Olsson ${ }^{1}$
}

\begin{abstract}
The ecosystem services (ES) concept refers to benefits that humanity receives from nature. Investigating how this concept has been embraced within urban planning is important when assessing the awareness of human dependence on natural functions and the potential for the ES concept to increase this awareness. We analyzed planning documents from three small and three large municipalities in southern Sweden to see how explicitly the ES concept was addressed and which individual services were mentioned. We found that five of the municipalities mentioned the ES concept explicitly and the remaining municipality addressed it implicitly. Comprehensive and green plans referred to the ES concept more explicitly than did plans that focused on a single issue. We used 23 individual ES as a reference; each was mentioned in at least one document, but those concerning habitat and recreation were mentioned most frequently. Individual ES were generally described at an elaborate level. No major differences were identified between large and small municipalities except that large ones mentioned more individual ES. Our study demonstrates that municipalities in southern Sweden have started to integrate the ES concept into their planning documents. However, there is great potential to increase and concretize the awareness of ES.
\end{abstract}

Key Words: green infrastructure; municipalities; nature-based solutions; public policy; spatial planning; Sweden

\section{INTRODUCTION}

\section{Ecosystem services in an urbanizing world}

The world is becoming more and more urbanized, which significantly affects urban ecosystems and the provisioning of ecosystem services (ES; Grimm et al. 2008). ES is a concept used to describe functions performed by nature that directly or indirectly benefit humankind and contribute to human well-being (MEA 2005a, TEEB 2011). Water regulation, air quality regulation, and recreation are examples of individual services known to be important to support health and well-being in an urban context (Gómez-Baggethun and Barton 2013). A key advantage of the ES concept is its educational potential that may increase stakeholders' understanding of the importance of protecting natural functions (Hauck et al. 2013, Beery et al. 2016). Urban green or blue spaces, often referred to as green infrastructure (GI), are important for the production of ES, and it is therefore important to manage such structures in an intelligent way in urban planning (McPhearson et al. 2014). However, there is often a conflict of interests between preserving urban green space and GI and exploitation for housing and industry, especially when cities are growing by means of densification (Haaland and Konijnendijk van den Bosch 2015). To steer urban development in a direction in which human and natural systems can coexist and the functions of ecosystems are maintained, there is a need for holistic policies with long-term perspective (Colding 2007, Woodruff and BenDor 2016). It is therefore increasingly important to understand how the ES concept is being considered in policy documents governing urban planning (Wilkinson et al. 2013, Albert et al. 2016).

\section{Ecosystem services in policy}

Policy documents may reflect the prevailing paradigm in a certain place at a certain point in time; this makes them interesting to study to follow the development of concepts and ideas (Howlett and Cashore 2009). Publication of the Millennium Ecosystem Assessment in 2005 (MEA 2005a) led to wide dissemination of ES as a concept and fueled its integration into policy (Kumar 2010, Schröter et al. 2014). Earlier studies have shown that the ES concept can occur in different ways in municipal planning documents: explicitly (concept mentioned directly and given a name) or implicitly (concept described but not given a name; Sitas et al. 2014, Hansen et al. 2015). Addressing ES explicitly in urban policies could possibly contribute to strengthen environmental aspects of urban planning, to the benefit of human health and well-being (Nin et al. 2016). Research has shown that the explicit use of the ES concept is still a relatively new phenomenon, even though the concept is becoming more known (Colding 2011, Woodruff and BenDor 2016).

In Sweden, the ES concept has been integrated to a certain extent into policy at the national level. In 2012, two targets concerning ES were added to the Swedish national environmental objectives: one calling for the identification of important ES and the other one stating that the importance of biodiversity and the value of ecosystem services should be known and integrated into economic positions, political considerations, and other planning decisions in society by 2018 at the latest (Miljödepartementet 2012).

The way to reach these goals and promote the ES approach was discussed in the national report Making the Value of Ecosystem Services Visible (Miljödepartementet 2013). Furthermore, in June 2014, the Swedish parliament adopted "A Swedish strategy for biodiversity and ecosystem services" (Prop. 2013/14:141), which, among other things, treats the subject of economic valuation of ES and provides guidance to regional and local authorities on how to work with ES. The strategy intends to contribute to the Swedish fulfillment of international commitments such as the Aichi Targets (United Nation 1992) and the EU 2020 Biodiversity Strategy (EC 2011). 


\section{The Swedish planning context}

Spatial planning in Sweden is regulated by the Swedish Plan and Building Act (SFS 2010:900). Municipalities are the main planning actors and hold a so-called "municipal planning monopoly" (Boverket 2016a). There are two types of plans within municipal planning: comprehensive plans and detailed development (local) plans. Comprehensive plans are not legally binding but constitute the overarching, guiding documents, which set the long-term agenda for land use within a municipality. Every municipality must have a valid comprehensive plan that fulfills certain criteria, according to Chapter 3 in the Swedish Planning and Building Act (SFS 2010:900). Local plans regulate land and water use as well as the rights and duties of different actors within a defined area, and they are legally binding (Boverket 2014). Connected to and usually serving as background information for the comprehensive plan, there are often additional plans focusing on, for example, green space, climate, traffic, and energy (Boverket 2016b).

\section{Study focus}

To consider ES in planning documents at lower levels, e.g., local plans, it has been argued that the ES concept needs to be included in strategic, guiding documents such as the comprehensive plans (Nahlik et al. 2012). This argument has also been forwarded in some recent Swedish studies in which Swedish land-use planners were interviewed (Delshammar 2015, Hanson et al. 2016). Previous studies have also shown that small municipalities tend to have less-developed environmental works than do large ones, e.g., in terms of having locally set up environmental targets, fulltime employed staff responsible for environmental issues, etc., which to a large extent is due to a lack of competencies and financial resources (Storbjörk 2004, SKL 2012). However, there is a lack of Swedish studies examining comprehensive plans with respect to the inclusion of the ES concept, the representation of individual ES, and differences between small and large municipalities. Our aim was to increase the knowledge of how and to what extent the ES concept has been integrated into Swedish urban planning by analyzing strategic policy documents from a number of municipalities.

We sought to answer the following questions. (1) In what way (explicitly or implicitly) is the ES concept addressed in municipal planning documents? (2) Which individual ES are most frequently mentioned and on what level of detail are the different ES described? (3) How many individual ES are mentioned in the various planning documents and by each municipality? (4) Do large municipalities refer to ES more explicitly or mention more ES than do small municipalities? (5) Does an explicit use of the ES concept correlate with more individual ES being mentioned?

\section{METHODS}

\section{Selection of municipalities}

Western Scania, in southern Sweden, is among the most densely populated regions in Sweden, is dominated by intensively managed arable soils, and holds a comparatively low proportion of green areas accessible by the public (Region Skåne 2012). Moreover, the population is increasing in most municipalities in this region (SCB 2016), and a common strategy to meet the subsequently increased need for housing is through densification (Region Skåne 2012). Given these conditions, it is especially interesting to examine how municipalities in western Scania have embraced the ES concept. Six municipalities were chosen for the study: three large (population wise), i.e., Malmö, Lund, and Helsingborg; and three small, i.e., Staffanstorp, Burlöv, and Höganäs. The three smaller municipalities are all situated next to one (or two) of the larger cities, which should minimize variation due to differences in the surrounding landscape (Fig. 1). Population densities and other case-study descriptions for the different municipalities are given in Table A.1.1 (Appendix 1).

Fig. 1. Locations of the selected municipalities in the southwestern part of Scania County in southernmost Sweden. The municipalities were located in areas dominated by arable (yellow) and urban (grey) land, with a low percentage of forest (green) and water bodies (blue; Lantmäteriet 12014/00579).

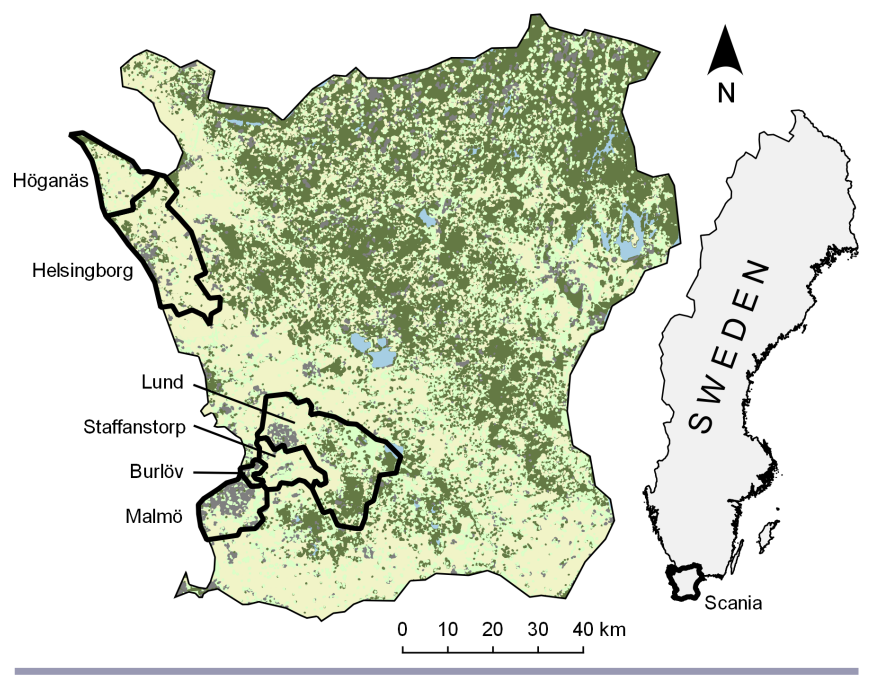

\section{Selection of documents}

Policy documents related to strategic spatial planning were collected from the official municipal websites and by consultation with employees from different sectors within the municipal organizations during February and March 2016. The following criteria were used for selection: the documents should (1) concern spatial planning on a strategic level (i.e., excluding local plans), (2) be put into force and still be in use, and (3) cover the central urban area of the municipality. The documents were divided into three categories based on their type and content (based on Hansen et al. 2015): comprehensive planning (CP), green planning (GP), and sectorial planning (SP). $\mathrm{CP}$ documents comprised comprehensive plans, including pertinent supplements. GP documents comprised green, environmental, or nature conservation programs, including associated action plans. SP documents focused on a single issue such as climate adaptation or storm water treatment. Each document was assigned a name consisting of the first three letters of the municipality's name followed by a number; document numbers were by category, with CP lowest, followed by GP and then SP.

\section{Document analysis}

Presence of the ecosystem services concept

Each document was analyzed with regard to the way in which the general ES concept occurred: explicitly, implicitly, or missing (Fig. 2A), following Hansen et al. (2015). Frequency was not recorded, only the most in-depth way in which ES was mentioned. That is, 
Fig. 2. Ecosystem services (ES) categorization criteria. The criteria are illustrated using fictitious examples for the different ways the ES concept could occur in documents (A) and the different levels of detail with which individual ES could be described (B). Data processing is described for both (A) and (B).

\section{A. Presence of the ES concept}

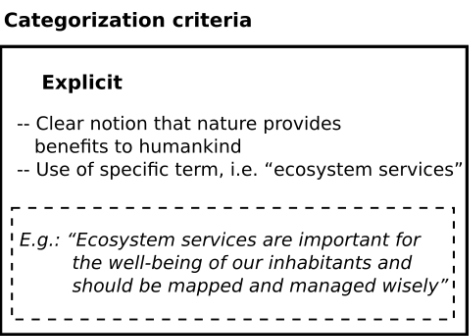

\begin{tabular}{l} 
Data processing \\
\begin{tabular}{|l|}
\hline - Proportion of documents \\
where the ES concept is \\
present explicitly/implicitly/ \\
missing calculated \\
per municipality \\
(incl. size groups), \\
year of adoption, \\
document category
\end{tabular} \\
\hline
\end{tabular}

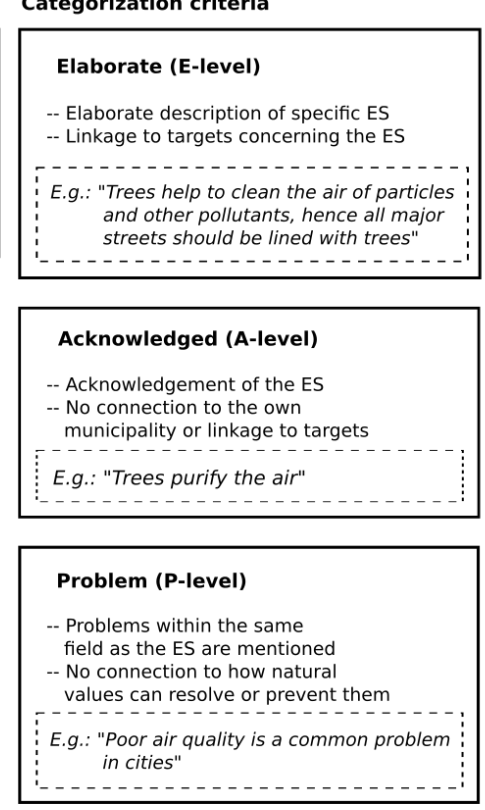

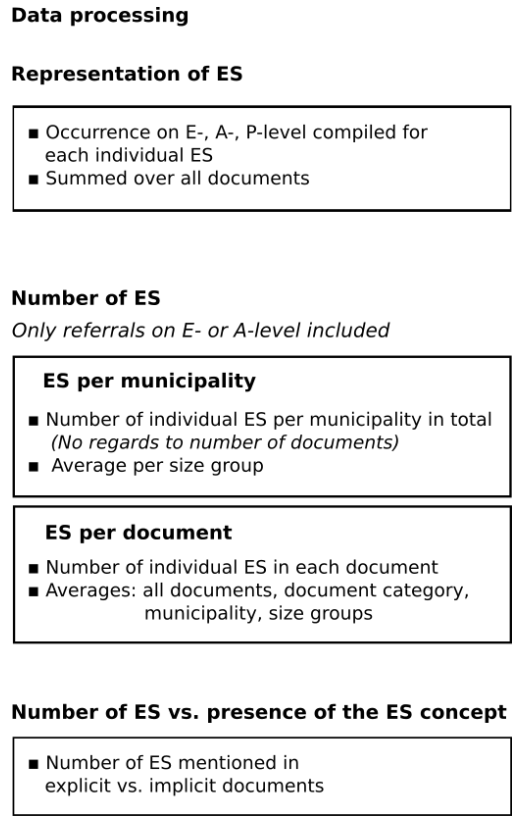

if a document addressed the ES concept implicitly on one page and explicitly on another, the document was counted as explicit. The proportions of documents addressing the ES concept explicitly, implicitly, or not at all were calculated with regard to municipality size, year of adoption, and document category.

\section{Representation of individual ecosystem services}

We also examined the use and frequency of individual ES. To limit the scope, we selected 23 individual ES listed in one or both of the two seminal reports covering the ES field (MEA 2005a, TEEB 2011) and considered relevant in an urban and Swedish context (Table 1). In these reports, ES are divided into four general categories: "regulating," "provisioning," "supporting," and "cultural," where the supporting category is considered a base for the remaining services. The 23 selected ES represent all four categories. Genetic resources or diversity, which is placed in different categories by MEA (2005a) and TEEB (2011; i.e., provisioning and supporting, respectively), was here called biodiversity and grouped with the service "habitat for species" in the supporting category because these issues tended to be treated as one within the municipal documents.

Referrals to individual ES were categorized into three levels regarding the degree of elaboration: elaborate (E), acknowledged (A), or problem mentioned but not the ES (P; Fig. 2B; Hansen et al. 2015). Only the most in-depth way of elaboration was recorded. The occurrence of individual ES was assessed in all documents, and the resulting compilation was used to describe which individual ES and ES categories were most or least represented. This part of the study made no distinction between implicit or explicit
Table 1. Individual ecosystem services considered in the study. The 23 different ecosystem services were divided into four categories based on the Millennium Ecosystem Assessment (2005a) and TEEB (2011).

\begin{tabular}{ll}
\hline \hline Category & Ecosystem service \\
\hline Regulating & Local climate regulation \\
& Air quality regulation \\
& Carbon sequestration and storage \\
& Water regulation \\
& Moderation of extreme events \\
& Wastewater treatment \\
& Erosion prevention \\
& Pollination \\
& Biological pest control \\
& Habitat for species and biodiversity \\
Supporting & Nutrient cycling \\
& Water cycling \\
& Photosynthesis and primary production \\
& Soil formation \\
& Food \\
& Fresh water \\
& Raw materials \\
& Natural medicinal resources \\
& Recreation and mental and physical health \\
& Tourism \\
& Aesthetic appreciation and inspiration \\
& Spiritual and religious values and sense of place \\
& Educational values \\
\hline
\end{tabular}


terminology, i.e., individual ES did not need to be called by the same name in the documents as in the check list (Table 1) in order to count as being mentioned (see Fig. 2B).

\section{Number of individual ecosystem services per municipality, size group, and document}

To examine the number of individual ES addressed per municipality, size group (small or large municipalities), and document category, a set of quantitative summaries was made. For an individual ES to be included in these summaries, elaboration at the level of E or A (see Fig. 2B) was required. For the total number of individual ES mentioned by each municipality, each individual ES was only recorded once per municipality, regardless of the number of documents in which the ES was addressed. The average number of ES mentioned was summarized for each size group. Furthermore, the average number of ES mentioned per document was calculated for all documents, the two municipal size groups, and each document category.

\begin{abstract}
Number of ecosystem services compared to presence of the concept

To examine whether explicit terminology seemed to generate greater awareness of ES in general, the use of the ES concept was compared to the number of individual ES addressed in the documents (Fig. 2B). The documents were grouped based on their way of referring to the ES concept (explicitly or implicitly), and the average number of individual ES mentioned in each group was calculated. For logical reasons, no calculations as such were made for the documents in which the ES concept was missing because the total absence of the ES concept implies that no individual ES were mentioned, according to our study methods.
\end{abstract}

\section{RESULTS}

Altogether, 39 documents were found to be relevant for the analysis. These documents had all been put into force between 2002 and 2016. The smaller municipalities generally had fewer than half as many documents as the larger ones (Table 2).

\section{Presence of the ecosystem services concept}

A total of 21 documents mentioned ES explicitly, 16 implicitly, and 2 not at all. All municipalities apart from Staffanstorp addressed ES explicitly in some of their documents (Fig. 3). Burlöv mentioned ES explicitly in all of its documents (3 of 3), Höganäs and Malmö in half of theirs (3 of 6 and 5 of 10 , respectively), Lund in 4 of 10, and Helsingborg in 6 of 8 documents. All remaining documents referred implicitly to ES, except the public health policies of Malmö and Lund (Mal_8, Lun_10), in which the concept was missing.

Small and large municipalities mentioned ES explicitly in approximately the same proportions of their documents (small: $55 \%$, large: $54 \%$ ). There was some difference between size groups in the proportion of documents mentioning ES implicitly (small: 45\%, large: $39 \%$ ).

The proportion of documents mentioning ES explicitly increased while the proportion of documents mentioning ES implicitly decreased over time (Fig. 4). Burlöv's environmental program (Bur_2) from 2009 was the oldest document mentioning ES explicitly (Table 2). After 2009, the concept of ES was addressed explicitly in at least one document from each year.
Fig. 3. Numbers of documents from each municipality referring to ecosystem services explicitly, implicitly, or not at all.

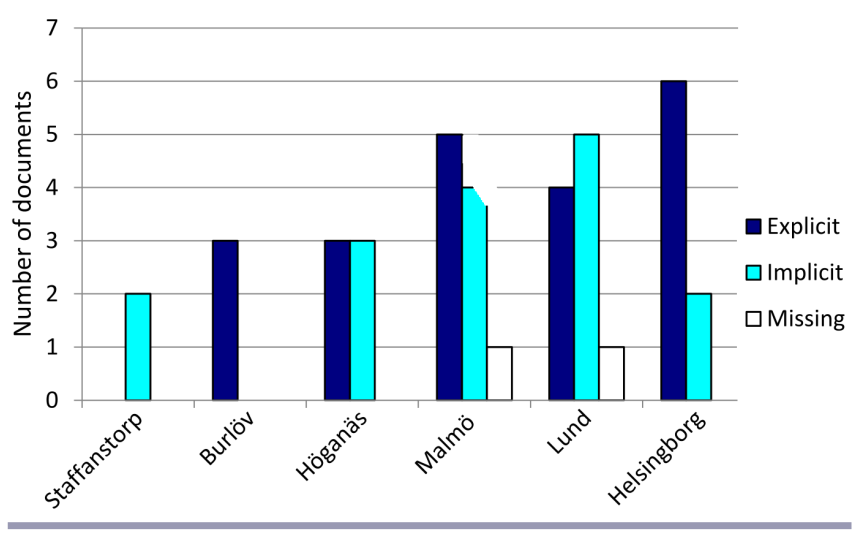

Fig. 4. Numbers of documents mentioning the ecosystem services concept explicitly, implicitly or not at all vs. the year of adoption.

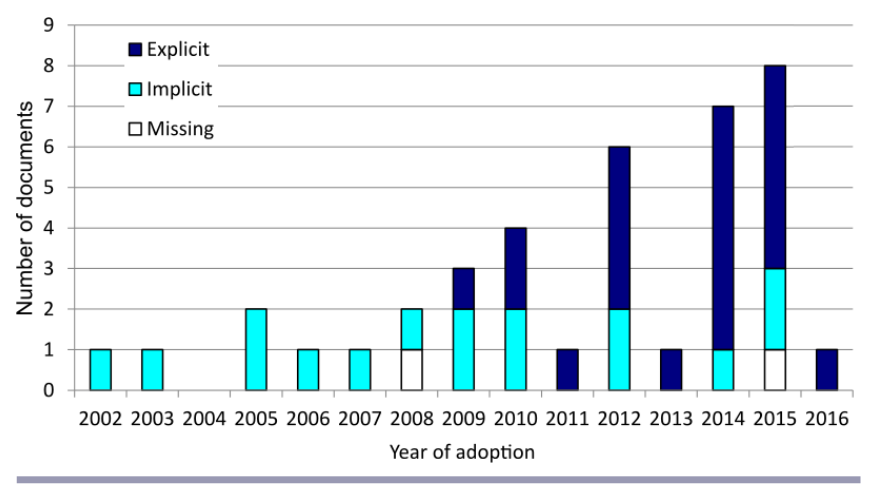

Furthermore, documents belonging to the GP category mentioned ES explicitly to a higher extent than did documents from other categories. ES was mentioned explicitly in $69 \%$ of GP documents compared to $55 \%$ of CP and $33 \%$ of SP documents (Fig. 5). Only SP contained some documents in which the ES concept was never mentioned.

Fig. 5. Proportions of documents mentioning the ecosystem services concept explicitly, implicitly, or not at all for each of the three document categories.

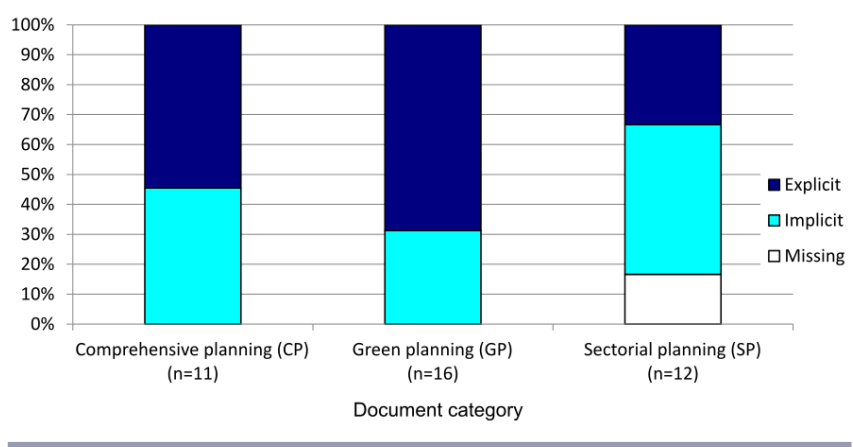


Table 2. Summary of the 39 documents examined from the six municipalities regarding the year of adoption, document category (CP = comprehensive planning, $\mathrm{GP}=$ green planning, $\mathrm{SP}=$ sectorial planning), way in which the concept of ecosystem services (ES) was present (explicit, implicit, or missing), and number of individual ES that were addressed (maximum $=23$ ).

\begin{tabular}{|c|c|c|c|c|c|c|c|c|}
\hline Municipality & Document & $\begin{array}{l}\text { Year of } \\
\text { adoption }\end{array}$ & Category & Explicit & Implicit & Missing & $\begin{array}{l}\text { Num- } \\
\text { ber of } \\
\text { ES }\end{array}$ & Document title \\
\hline \multirow[t]{2}{*}{ Staffanstorp } & Sta_1 & 2009 & $\mathrm{CP}$ & & $\mathrm{X}$ & & 10 & ÖP: Framtidens kommun \\
\hline & Sta_2 & 2010 & GP & & $\mathrm{X}$ & & 6 & Grönplan \\
\hline \multirow[t]{3}{*}{ Burlöv } & Bur_1 & 2014 & $\mathrm{CP}$ & $\mathrm{X}$ & & & 15 & ÖP: Framtidsplan \\
\hline & Bur_2 & 2009 & GP & $\mathrm{X}$ & & & 13 & Miljöprogram \\
\hline & Bur_3 & 2015 & SP & $\mathrm{X}$ & & & 7 & Dagvattenstrategi \\
\hline \multirow[t]{6}{*}{ Höganäs } & Hög_1 & 2002 & $\mathrm{CP}$ & & $\mathrm{X}$ & & 9 & ÖP 2002 \\
\hline & Hög_2 & 2012 & $\mathrm{CP}$ & $\mathrm{X}$ & & & 11 & $\begin{array}{l}\text { Fördjupning av översiktsplanen för } \\
\text { Höganäs och Väsby }\end{array}$ \\
\hline & Hög_3 & 2015 & GP & $\mathrm{X}$ & & & 5 & Miljöprogram \\
\hline & Hög_4 & 2015 & GP & $\mathrm{X}$ & & & 2 & Åtgärdsplan till miljöprogrammet \\
\hline & Hög_5 & 2012 & SP & & $\mathrm{X}$ & & 5 & KlimatPM \\
\hline & Hög_6 & 2015 & SP & & $\mathrm{X}$ & & 1 & Folkhälsoprogram \\
\hline \multirow{10}{*}{ Malmö } & Mal_1 & 2014 & $\mathrm{CP}$ & $\mathrm{X}$ & & & 12 & Översiktsplan för Malmö - Planstrategi \\
\hline & Mal_2 & 2014 & $\mathrm{CP}$ & $\mathrm{X}$ & & & 6 & $\begin{array}{l}\text { Utvecklingsplan med } \\
\text { gestaltningsprinciper }\end{array}$ \\
\hline & Mal_3 & 2003 & GP & & $\mathrm{X}$ & & 9 & Grönplan \\
\hline & Mal_4 & 2012 & GP & $\mathrm{X}$ & & & 11 & Naturvårdsplan del 1 \\
\hline & Mal_5 & 2009 & GP & & $\mathrm{X}$ & & 5 & Miljöprogram \\
\hline & Mal_6 & 2010 & GP & $\mathrm{X}$ & & & 11 & Handlingsplan för miljöprogrammet \\
\hline & Mal_7 & 2015 & GP & $\mathrm{X}$ & & & 6 & Hållbarhetsstrategi Norra Sorgenfri \\
\hline & Mal_8 & 2015 & SP & & & $\mathrm{X}$ & 0 & Folkhälsopolicy \\
\hline & Mal_9 & 2005 & SP & & $\mathrm{X}$ & & 12 & Trädplan \\
\hline & Mal_10 & 2008 & SP & & $\mathrm{X}$ & & 7 & Dagvattenstrategi \\
\hline \multirow[t]{10}{*}{ Lund } & Lun_1 & 2010 & $\mathrm{CP}$ & & $\mathrm{X}$ & & 14 & ÖP 2010 \\
\hline & Lun_2 & 2005 & $\mathrm{CP}$ & & $\mathrm{X}$ & & 11 & Värna och vinna staden \\
\hline & Lun_3 & 2007 & $\mathrm{CP}$ & & $\mathrm{X}$ & & 2 & Utbyggnadsprogram \\
\hline & Lun_4 & 2014 & GP & $\mathrm{X}$ & & & 9 & Lundaeko II \\
\hline & Lun_5 & 2015 & GP & $\mathrm{X}$ & & & 16 & Balanseringsprincipen i Lunds kommun \\
\hline & Lun_6 & 2006 & GP & & $\mathrm{X}$ & & 14 & Grönstruktur- och naturvårdsprogram \\
\hline & Lun_7 & 2014 & GP & & $\mathrm{X}$ & & 5 & GNP 2015-2017 \\
\hline & Lun_8 & 2013 & SP & $\mathrm{X}$ & & & 7 & Dagvattenstrategi \\
\hline & Lun_9 & 2012 & SP & $\mathrm{X}$ & & & 5 & Trädplan \\
\hline & Lun_10 & 2008 & SP & & & $\mathrm{X}$ & 0 & Folkhälsopolicy \\
\hline \multirow[t]{8}{*}{ Helsingborg } & Hel_1 & 2010 & $\mathrm{CP}$ & $\mathrm{X}$ & & & 14 & ÖP 2010 \\
\hline & Hel_2 & 2011 & $\mathrm{CP}$ & $\mathrm{X}$ & & & 9 & FÖP H+ \\
\hline & Hel_3 & 2016 & GP & $\mathrm{X}$ & & & 13 & Grönska och rekreation \\
\hline & $\mathrm{Hel}_{-} 4$ & 2014 & GP & $\mathrm{X}$ & & & 21 & Grönstrukturprogram \\
\hline & Hel_5 & 2014 & GP & $\mathrm{X}$ & & & 7 & Ett grönare Helsingborg \\
\hline & Hel_6 & 2012 & SP & $\mathrm{X}$ & & & 4 & Helsingborgs Livskvalitetsprogram \\
\hline & Hel_7 & 2012 & SP & & $\mathrm{X}$ & & 11 & PM Klimatanpassning \\
\hline & Hel_8 & 2015 & SP & & $\mathrm{X}$ & & 7 & Dagvattenpolicy \\
\hline
\end{tabular}

\section{Representation of individual ecosystem services}

All 23 individual ES were mentioned at the E or A level in at least one of the analyzed documents (Fig. 6; see also Appendix 2, Table A2.1). Approximately half of the ES in the regulating category and most in the cultural category were addressed in a relatively high number of documents (15-34 documents), whereas "habitat for species and biodiversity" was the only service from the supporting category to occur frequently ( 34 documents). Of the provisioning ES, all but "natural medicinal resources" were mentioned in 12 to 21 documents. Regarding similarities and differences between municipalities in terms of which ES they mentioned, it can be noted that nine services were addressed by every municipality: "water regulation," "moderation of extreme events," "waste water treatment," "habitat for species and diversity," "food," "fresh water," "raw materials," "recreation and mental and physical health," and "spiritual values and sense of place." Two services: "natural medicinal resources" and "carbon sequestration and storage" were only mentioned by one municipality (Helsingborg; Table 3).

Altogether, ES were most commonly mentioned at the elaborate level (E; Fig. 6). Three services were mentioned elaborately in many of the 39 documents: "water regulation" (25 documents), "habitat for species and biodiversity" (31), and "recreation and mental and physical health" (27). These three services represent all ES categories apart from provisioning services. The following E-level example describes the services "water regulation" and "moderation of extreme events" (freely translated from Sta_1, page 75):

To decrease the risk of flooding, retaining reservoirs along Sege River and Höje River are suggested, in order to delay storm water in case of heavy rains and provide 
Fig. 6. Numbers of documents mentioning each of the 23 individual ecosystem services considered in the study with respect to the level of detail with which they were described. Inspired by Hansen et al. (2015).

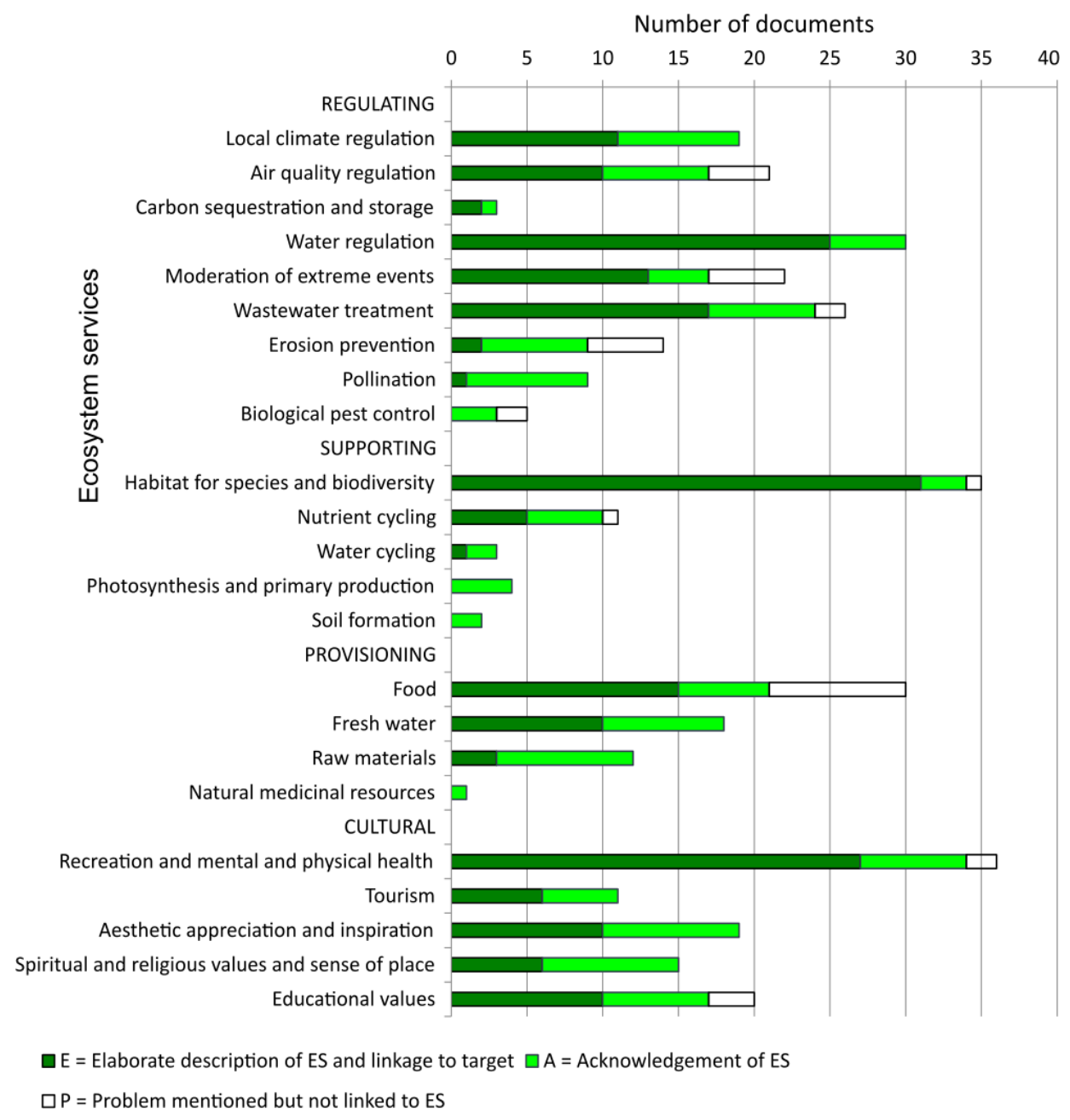

the rivers the possibility of flooding when needed. Local delay of storm water and open storm water solutions are often economically beneficial, as the construction costs are normally lower than traditional storm water solutions and a decrease in flooding contributes to lower sanitation costs.

Some referrals to individual ES at the A level consisted of simply explaining the concept of ES and providing some examples of services, without giving any details or connecting the considered services to the municipality in question. The services "biological pest control," "pollination," "natural medicinal resources," "photosynthesis and primary production," and "soil formation" were almost exclusively mentioned in this way. For the remainder, an A-level referral could look like the following example in which the services "local climate regulation" and "air quality regulation" are being addressed (freely translated from Mal_9, page 30):

The trees are needed as climate improvers, not least in the city where the drier climate causes large problems. The trees are most efficient as particle collectors, windbreakers, and emitters of oxygen and water vapour while they are in their leafed condition.

However, the document contained no targets on how to make use of the potential stated benefits.

Ten ES were mentioned at the $\mathrm{P}$ level in some document. For these services, the number of documents in which the same ES was mentioned at the A or E level was higher (Fig. 6). "Food," "erosion protection," and "moderation of extreme events" were mentioned at the P level in more documents than other services. The following example shows what the $\mathrm{P}$ level might look like for the service "biological pest control" (freely translated from Hel_7, page 32): "A changing climate is likely to entail a worsening situation regarding pathogens and insect pests." The statement was not followed by any thoughts on how nature-based solutions could be used to prevent the described scenario.

\section{Number of individual ecosystem services per municipality and document}

For all of these summaries, only the referrals to ES that occurred at the A or E level of detail (Fig. 2B) were included. Helsingborg 
Table 3. Summary of individual ecosystem services mentioned, by municipality.

\begin{tabular}{|c|c|c|c|c|c|c|c|}
\hline Ecosystem service & $\begin{array}{c}\text { Total number of } \\
\text { municipalities }\end{array}$ & Staffanstorp & Burlöv & Höganäs & Malmö & Lund & Helsingborg \\
\hline \multicolumn{8}{|l|}{ - Regulating services } \\
\hline Local climate regulation & 5 & & $\mathrm{X}$ & $\mathrm{X}$ & $\mathrm{X}$ & $\mathrm{X}$ & $\mathrm{X}$ \\
\hline Air quality regulation & 4 & & $\mathrm{X}$ & & $\mathrm{X}$ & $\mathrm{X}$ & $\mathrm{X}$ \\
\hline $\begin{array}{l}\text { Carbon sequestration and } \\
\text { storage }\end{array}$ & 1 & & & & & & $\mathrm{X}$ \\
\hline Water regulation & 6 & $\mathrm{X}$ & $X$ & $\mathrm{X}$ & $\mathrm{X}$ & $\mathrm{X}$ & $\mathrm{X}$ \\
\hline $\begin{array}{l}\text { Moderation of extreme } \\
\text { events }\end{array}$ & 6 & $\mathrm{X}$ & $X$ & $\mathrm{X}$ & $\mathrm{X}$ & $\mathrm{X}$ & $\mathrm{X}$ \\
\hline Wastewater treatment & 6 & $\mathrm{X}$ & $\mathrm{X}$ & $\mathrm{X}$ & $\mathrm{X}$ & $\mathrm{X}$ & $\mathrm{X}$ \\
\hline Erosion prevention & 4 & & & $\mathrm{X}$ & $\mathrm{X}$ & $\mathrm{X}$ & $\mathrm{X}$ \\
\hline Pollination & 5 & & $\mathrm{X}$ & $\mathrm{X}$ & $\mathrm{X}$ & $\mathrm{X}$ & $\mathrm{X}$ \\
\hline $\begin{array}{l}\text { Biological pest control } \\
\text { - Supporting services }\end{array}$ & 2 & & & & & $\mathrm{X}$ & $\mathrm{X}$ \\
\hline $\begin{array}{l}\text { Habitat for species and } \\
\text { biodiversity }\end{array}$ & 6 & $X$ & $\mathrm{X}$ & $\mathrm{X}$ & $\mathrm{X}$ & $\mathrm{X}$ & $\mathrm{X}$ \\
\hline Nutrient cycling & 5 & & $\mathrm{X}$ & $\mathrm{X}$ & $\mathrm{X}$ & $\mathrm{X}$ & $\mathrm{X}$ \\
\hline Water cycling & 3 & & & & $\mathrm{X}$ & $\mathrm{X}$ & $\mathrm{X}$ \\
\hline $\begin{array}{l}\text { Photosynthesis and primary } \\
\text { production }\end{array}$ & 3 & & & $\mathrm{X}$ & $\mathrm{X}$ & $X$ & \\
\hline $\begin{array}{l}\text { Soil formation } \\
\text { Provisioning services }\end{array}$ & 2 & & & & & $\mathrm{X}$ & $\mathrm{X}$ \\
\hline Food & 6 & $\mathrm{X}$ & $X$ & $\mathrm{X}$ & $\mathrm{X}$ & $\mathrm{X}$ & $\mathrm{X}$ \\
\hline Fresh water & 6 & $\mathrm{X}$ & $\mathrm{X}$ & $\mathrm{X}$ & $\mathrm{X}$ & $\mathrm{X}$ & $\mathrm{X}$ \\
\hline Raw materials & 6 & $\mathrm{X}$ & $\mathrm{X}$ & $\mathrm{X}$ & $\mathrm{X}$ & $\mathrm{X}$ & $\mathrm{X}$ \\
\hline $\begin{array}{l}\text { Natural medicinal resources } \\
\text { - Cultural services }\end{array}$ & 1 & & & & & & $\mathrm{X}$ \\
\hline $\begin{array}{l}\text { Recreation and mental and } \\
\text { physical health }\end{array}$ & 6 & $\mathrm{X}$ & $\mathrm{X}$ & $\mathrm{X}$ & $\mathrm{X}$ & $\mathrm{X}$ & $\mathrm{X}$ \\
\hline Tourism & 5 & $\mathrm{X}$ & & $\mathrm{X}$ & $\mathrm{X}$ & $\mathrm{X}$ & $\mathrm{X}$ \\
\hline $\begin{array}{l}\text { Aesthetic appreciation and } \\
\text { inspiration }\end{array}$ & 5 & & $\mathrm{X}$ & $\mathrm{X}$ & $\mathrm{X}$ & $\mathrm{X}$ & $\mathrm{X}$ \\
\hline $\begin{array}{l}\text { Spiritual and religious } \\
\text { values and sense of place }\end{array}$ & 6 & $\mathrm{X}$ & $X$ & $\mathrm{X}$ & $\mathrm{X}$ & $\mathrm{X}$ & $X$ \\
\hline Educational values & 5 & $\mathrm{X}$ & $\mathrm{X}$ & & $\mathrm{X}$ & $\mathrm{X}$ & $\mathrm{X}$ \\
\hline $\begin{array}{l}\text { - Total number of } \\
\text { ecosystem services } \\
\text { mentioned }\end{array}$ & & 11 & 15 & 16 & 19 & 21 & 22 \\
\hline
\end{tabular}

mentioned the highest number of ES (22), followed by Lund (21), and Malmö (19). Höganäs and Burlöv mentioned 16 and 15 services, respectively, and Staffanstorp mentioned 11 (Table 3). Thus, small municipalities mentioned an average of 14.0 different ES and large ones mentioned 20.7 ES.

On a per-document basis, on average, 8.5 ES were addressed when including all documents. There was only a small difference between small and large municipalities in this respect (7.6 vs. 8.9 ES/document). The CP category contained the highest average number of ES per document (10.3), followed by GP (9.6), and finally, SP (5.5; Fig. 7). The individual documents mentioning the most ES mainly consisted of the main comprehensive plan (CP category) and GP documents focusing on green infrastructure and nature conservation (Table 2). The documents mentioning the fewest ES were predominantly SP documents focusing on public health.

\section{Number of ecosystem services compared to presence of the concept}

Documents addressing ES implicitly mentioned on average 8.0 individual services per document. The corresponding figure for those addressing ES explicitly was 9.4 (Fig. 8, Table 2).

\section{DISCUSSION}

\section{Presence of the ecosystem services concept}

Municipalities in our study referred explicitly to the ES concept in their policy documents to a larger extent than has been found in earlier Swedish studies covering municipalities across all of Sweden (Delshammar 2015, Hanson et al. 2016). This might be explained partly by geographical factors; we focused on a region poor in green and blue space; hence, more proactive work may be required to maintain natural functions as compared to other Swedish municipalities that are surrounded by more undeveloped nature. We also showed that an absence of the explicit term "ecosystem services" in policy documents did not necessarily mean that the concept was not recognized. Many of the documents that only addressed ES implicitly still contained detailed descriptions of individual services linked to targets, a phenomenon that has also been noted in other studies (e.g., Hauck et al. 2013, Hansen et al. 2015, Beery et al. 2016, Wamsler et al. 2016). 
Fig. 7. Numbers of individual ecosystem services (ES) mentioned in each document based on document category, i.e., comprehensive planning (CP), green planning (GP), or sectorial planning (SP). Dotted lines indicate the mean number of ES per document (CP: 10.3, GP: 9.6, and SP: 5.5).
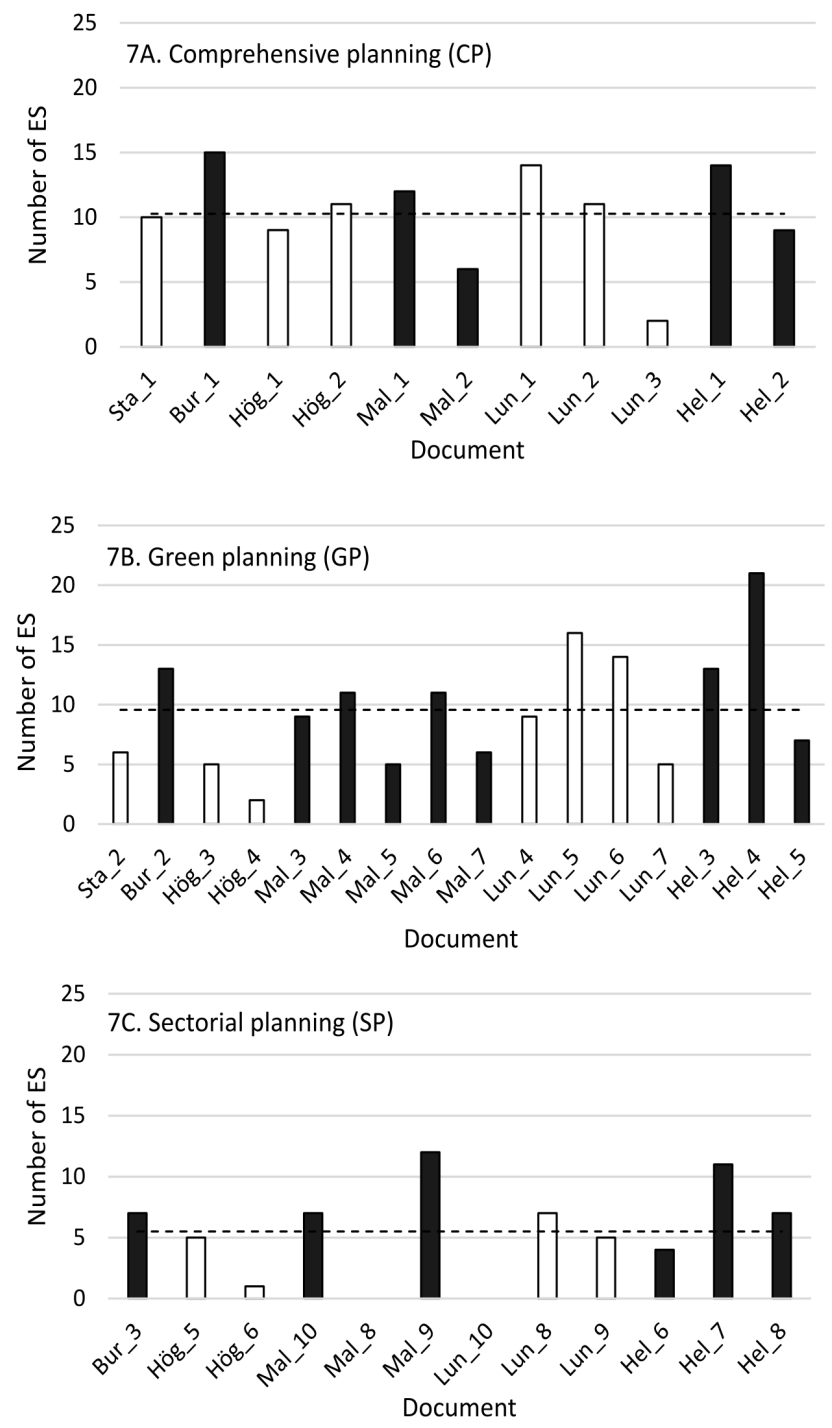

Overall, there was no difference between the smaller and larger municipalities regarding the proportion of documents addressing ES explicitly, even though the small municipality Staffanstorp was the only one not to mention ES explicitly in any document. One explanation could be that western Scania has a high mobility of people, institutions of higher education in all the three larger cities, and intermunicipal cooperation in many areas (Region Skåne 2006). For example, an interdisciplinary research project concerning ES ("ECOSIMP") took place in the region during 2013-2016, involving all three large municipalities and four others (Jönsson et al. 2017). The possibilities of exchanging information and collaborating on a regional level may have contributed to even
Fig. 8. Numbers of individual ecosystem services (ES) mentioned in documents that refer to the concept of ES explicitly or implicitly. Each box represents the two quartiles of the data around the median (middle line) and each whisker another quartile.

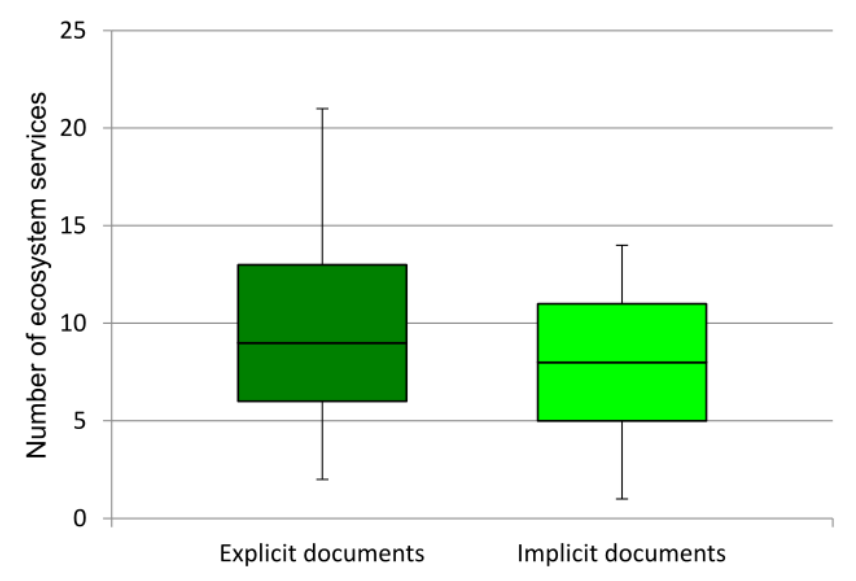

out differences concerning the ES concept between municipalities of different size and should provide good conditions for regional policy development in this region. Another explanation could be that large municipalities tend to have a higher number of documents than smaller ones, which potentially may even out differences between the two groups. Therefore, to make more certain conclusions regarding size-dependent variation, future studies should include a larger set of municipalities and a way to handle the varying number of documents per municipality.

In the studied documents, the term ES was explicitly mentioned for the first time in 2009 (Bur_2). This could be considered as relatively early, bearing in mind that the concept of ES was not particularly well spread until after the Millennium Ecosystem Assessment in 2005 (MEA 2005a) and was not integrated in Swedish national environmental targets until 2012. Development of municipal plans and programs can be a rather slow process; hence, a delay can be expected before new concepts emerge in these documents (Bradshaw and Borchers 2000), especially because there are no clear pathways for how the concept should be integrated in practice (Wamsler et al. 2014). The proportion of documents mentioning ES explicitly was at least 50\% each year from 2009 and onward, suggesting that the concept made something of a breakthrough in those years. This observation indicates that concepts such as ES actually can find their way into strategic municipal documents relatively quickly. It has been argued that this may be because ES was addressed, at least implicitly, already before the explicit concept entered the international policy sphere (Maczka et al. 2016). Additionally, there may have been a "contagious" effect between municipalities in the study region with regard to the uptake of ES terminology because of the high level of interlinkage through different regional cooperative organs (e.g., Kommunförbundet Skåne and Region Skåne). 
GP was the document category in which ES was mentioned explicitly to the highest degree. This result is not surprising because knowledge of ES can be expected to be higher among those working with environmental and nature conservation issues (Sitas et al. 2014). Nevertheless, important decisions affecting ES are often taken by others than those responsible for green issues (MEA 2005b). It is therefore gratifying to see that ES was mentioned explicitly to a high degree in the CP category, which can be interpreted as a sign that knowledge about ES is spreading beyond the green sphere or, alternatively, that ecological competence has been integrated into the development of comprehensive plans and programs.

For the SP category, it was surprising that ES was not mentioned explicitly to a greater extent, especially because many of the documents covered topics in which individual ES were described at a detailed level. For example, Helsingborg's storm-water policy (Hel_8) mentioned seven individual ES at the A or E level but never mentioned the term ES explicitly, despite that the document was adopted in 2015 and several other documents from the same municipality had already mentioned ES explicitly. In short, although there is knowledge as to how nature can be used to achieve certain desired effects, the expression "ecosystem services" is not always used explicitly. This phenomenon in which conceptual knowledge occurs more frequently in early than in later phases of policy development has been noted previously (McKenzie et al. 2014, Nahlik et al. 2012). Here, the phenomenon might be illustrated by the loss of the conceptual term ES from high-level policy documents (CP) to lower levels, closer to application (SP). The prevailing situation in the SP documents (elaborated descriptions of individual ES despite no explicit referral to the general ES concept) could be considered to have a greater potential to promote ES at the operational level than the use of an explicit terminology lacking descriptions and targets for individual ES. However, it has been argued that if one of the main benefits of the ES concept is its educational value, it is important to discuss actually it in explicit terms (Beery et al. 2016). Furthermore, Nahlik et al. (2012) recommend that the practical implementation of ES measures should be built upon a base of shared conceptual knowledge because this ensures better collaboration, communication, and understanding. To ensure awareness at all strategic levels regarding why specific natural functions are being targeted, it might therefore prove valuable if the general ES concept is present even in operational documents (SP category) and not just in the overarching guidelines.

It is notable that the only two documents that completely lacked the concept of ES concerned public health. This is especially surprising for Mal_8 because it entered into force in 2015 (see, for example, Lun_10:2008) and indicates a lack of understanding among public health officers of the potential for nature to support public health efforts. This situation is symptomatic of how different sectors of the municipal organization tend to operate separately and how different skills are separated from one another (Primmer and Furman 2012). However, to work with such a complex concept as ES in practice, a holistic approach is required whereby different departments collaborate rather than act within their own silos (Colding 2007). Conversely, there is some evidence that the ES framework itself can foster interdepartmental communication (Rall et al. 2015).
Finally, the presence of a theoretical concept within policy documents is not a complete indicator of how the concept is translated into practice (Primmer and Furman 2012). In other words, the work is not completed when the right terminology is in place; instead, to make a real difference, it requires that urban planners actively incorporate the practical consequences of the concept in strategic planning documents that are closer to the implementation. Future studies should therefore examine the presence of ES in documents further down the policy chain (such as local plans), the municipal process of local plan developent, what concrete actions municipalities are taking to promote ES, and whether the ES concept may increase communication between different municipal departments and other involved actors such as construction companies.

\section{Representation of individual ecosystem services}

Of the four ES categories, supporting services stands out as the most inadequately represented. Services in this category, such as "soil formation" and "photosynthesis and primary production," are examples of ES that can be considered to lie outside the traditional municipal agenda, i.e., ES not directly associated with urban planning, as stated by Primmer and Furman (2012). However, supporting services provide a base for services in the three other ES categories (MEA 2005a) and may therefore be considered especially important to protect. Admittedly, not all ES are equally important for every city to work actively with, not least because of geographical and biological contexts (GómezBaggethun and Barton 2013). However, given the high urbanization rate and the fact that urbanization affects the ability of green spaces to generate ES (McKinney 2002, Niemelä et al. 2010), it is important to have a comprehensive understanding of how urban areas depend on various ES. The fact that there may be spatial and temporal discrepancy between where and when an ES is generated and where and when the effect of it becomes apparent means that the governance of ES might preferably take place at a local, regional, or higher levels depending on the context and type of targeted ES (McPhearson et al. 2014). Considering Scania's intermunicipal cooperations at the regional level, the premises for regional ES management, when appropriate, seem promising. Mapping the temporal and spatial scales of various ES is therefore important to manage them effectively (Kumar 2010), and this is an area for future research.

The elaborate level (E) was the most common way for individual ES to be mentioned, which implies a good understanding of the concept of ES and entails the existence of targets coupled to the ES in question. Although all $23 \mathrm{ES}$ examined here were mentioned in at least one document, some ES were clearly mentioned more frequently than others. This can probably be explained by the fact that the documents in question mainly concern urban areas, which in turn are more suitable for some types of ES than others, and that some ES may be better known than others. "Habitat for species and biodiversity" followed by "recreation and mental and physical health" constitute the two ES mentioned in most documents, whereas "biological pest control" and "natural medicinal resources" were among the least frequently mentioned services, which is in line with previous results (Hansen et al. 2015). The ES "recreation and mental and physical health" and "habitat for species and biodiversity" represent issues for which many municipalities already have much experience and competence (Hansen et al. 2015), which might explain the frequency of these 
services on an elaborate level. For some issues, there are national guidelines and legally binding instruments, e.g., Swedish environmental quality standards concerning air and water quality (NVV 2015). Having binding, high-level policy instruments in place has previously been noted as a factor that increases the likelihood of ES work to be realized in practice (MEA 2005b, Hansen et al. 2015). This may explain why ES related to areas covered by national legislation or policy are mentioned more frequently and more elaborately by all municipalities (e.g., "wastewater treatment," "air quality regulation") than other ES. In contrast, the tradition of working with technical rather than nature-based solutions to cope with problems such as erosion and moderation of extreme natural events (Rydell and Lundström 2013) may explain why ES related to these problems were addressed at the $\mathrm{P}$ level to a higher degree compared to services relating to nature conservation and recreation. Nature-based solutions have been put forward as important for climate change adaptation (EC 2015); thus, increased knowledge about how ES might be used to handle issues traditionally managed with technical solutions is needed. To increase the inclusion of the least mentioned and least elaborated described ES such as "biological pest control" and "photosynthesis and primary production" in planning documents, there is a need to put those services into context. For example, biological pest control and pollination are important ES for urban gardening, and municipalities could therefore use urban gardening as an example to describe the usefulness of those two services within an urban context.

The 23 individual ES included here do not constitute an exhaustive list of all services provided by nature. The numerical results would therefore be altered to some extent by using a different selection of ES. The figures produced here are primarily intended to be used as indicators of how and which individual ES are covered in municipal planning and not to be construed as an absolute truth.

\section{Number of individual ecosystem services per municipality and document}

Because different documents may be intended to complement one another, some issues might deliberately be left out in one document to be treated in another. This could generate a low number of individual ES per document but still a high number of ES per municipality. The total number of ES addressed per municipality could therefore be interpreted as an indicator of how many and which services a municipality is indeed aware. To mention a high number of individual ES and not just discuss ES as a general concept might render the concept easier to comprehend and conceivably increase the likelihood of not losing the ES agenda along the way from general strategies and plans to lower level documents such as detailed plans (Wissen Hayek et al. 2016).

Smaller municipalities mentioned considerably fewer ES in total than did their larger counterparts. One explanation may be a lower awareness and a lower level of ambition when it actually comes to integrating ES and nature-based solutions into practice and not just discuss ES on a conceptual level. The large municipalities of Helsingborg and Malmö seem to have taken the role as forerunners when it comes to these matters. For example, both cities are participating in the international project "Local Governments for Sustainability" (ICLEI, http://www.iclei- europe.org/members/who-are-our-members/), in which ecosystem services constitute a key issue. Malmö has also led a research project analyzing the support of the Planning and Building Act (SFS 2010:900) for municipalities to work with ES (Hanson et al. 2016). Economic and human resources and the possibility of learning from the experiences of other municipalities are all factors identified as being important for a municipality's opportunity to work with environmental issues according to the intermunicipal organization SKL (2012). Large municipalities are often better off than small ones when it comes to these factors. For example, small and large municipalities have approximately the same duties when it comes to urban planning, but large municipalities tend to have more human resources to fulfill these duties. These factors could also influence to what extent a municipality integrates new scientific concepts into its policy documents. However, our study also shows that even small municipalities such as Burlöv can have high ambitions concerning the work with individual ES.

The average number of $8.5 \mathrm{ES}$ per document may appear relatively low compared to the highest possible value in the study (23). Even when breaking the numbers down based on municipal size groups or document categories, the large municipalities and the most general category (CP) did not score higher than 8.9 and 10.3 ES per document, respectively. Thus, there is potential to increase these figures given that most types of policy documents could address several different ES.

The relatively large gap between the number of ES in the various document categories is not surprising because different types of documents serve different purposes. SP is inherently more limited in terms of what it concerns, whereas CP covers a wide range of subjects, and GP deals specifically with areas related to ES. Thus, the two latter document categories can be expected to address a larger number of ES than does SP (Hansen et al. 2015).

One document which could be expected to mention a larger number of ES than what we found was Lund's action plan for green structure (Lun_7), which was adopted in 2014 and specifically treats green space but only mentions five services. This is especially remarkable because the strategic program (Lun_6) to which the action plan is linked mentions a higher number of ES, even though it was adopted in 2006. The same pattern is observed for Höganäs' action plan (Hög_4), which is linked to a strategic environmental program (Hög_3). This leads to the interpretation that the knowledge of ES has lost ground from the strategic to the operational level, as noted above.

Public health documents (category SP) generally appeared to cover very few services (if any). This occurrence is despite the fact that a number of cultural ES are directly related to human wellbeing, human health is affected by physical factors such as air quality and local climate (MEA 2005a, TEEB 2011), and "recreation and mental and physical health" was one of the most frequently mentioned services in our study documents. In other words, there is clear potential to enhance public health policy by making better use of green values. Ongoing climate change, which most likely will bring enhanced temperatures and more extreme weather events, makes an ES-based approach even more urgent (Wamsler et al. 2016), which regional institutions in Scania (Klimatsamverkan Skåne 2015) seem to be more aware of than the municipalities examined here. 


\section{Number of ecosystem services compared to presence of the concept}

Our results indicate that documents mentioning ES explicitly tend to mention a somewhat higher number of individual ES. This is interesting because it implies that the awareness of specific benefits that humanity gets from nature might increase with increasing awareness of ES as a concept. Hauck et al. (2013) argue along the same lines when suggesting that an explicit way of addressing the general ES concept makes it easier to identify how individual ES are affected by various measures, thus decreasing the risk of involuntarily promoting one service at the cost of another.

\section{CONCLUDING REMARKS}

The ES concept seems to be fairly well embraced by municipalities in southernmost Sweden. Five of six municipalities explicitly mentioned ES in their policy documents, and all provided examples of individual ES linked to targets. The individual ES "habitat for species and biodiversity" and "recreation and mental and physical health" were mentioned in the most documents. Large and small municipalities differed primarily in terms of how many ES each municipality mentioned, with larger municipalities mentioning more individual ES than smaller municipalities. Comprehensive plans and documents concerning nature conservation or green infrastructure had the highest uptake of the ES concept as well as referrals to individual ES, whereas documents concerning public health generally lacked the concept and only referred to a few (if any) individual ES.

In summary, these municipalities have come quite some way in integrating the ES concept into their plans and programs. This can be seen as an important step in the process of putting the idea of protecting, as well as benefitting from, ES into practice. However, our results also identify areas for further improvement. For example, the conceptual knowledge of ES could be further assured on all strategic levels, the term ES could be used explicitly to a higher degree, and a higher number of individual ES could be addressed and coupled to specific targets.

Responses to this article can be read online at: http://www.ecologyandsociety.org/issues/responses. php/9420

\section{Acknowledgments:}

We thank Oskar Löfgren, PhD at Lund University, for helping to produce Figure 1.

\section{LITERATURE CITED}

Albert, C., C. Galler, J. Hermes, F. Neuendorf, C. von Haaren, and A. Lovett. 2016. Applying ecosystem services indicators in landscape planning and management: the ES-in-Planning framework. Ecological Indicators 61(1):100-113. http://dx.doi. org/10.1016/j.ecolind.2015.03.029

Beery, T., S. Stålhammar, K. I. Jönsson, C. Wamsler, T. Bramryd, E. Brink, N. Ekelund, M. Johansson, T. Palo, and P. Schubert. 2016. Perceptions of the ecosystem services concept: opportunities and challenges in the Swedish municipal context. Ecosystem Services 17:123-130. http://dx.doi.org/10.1016/j. ecoser.2015.12.002

Boverket. 2014. Vad är en detaljpan? [What is a detailed development plan?] Boverket, Karlskrona, Sweden. [online] URL: http://www.boverket.se/sv/PBL-kunskapsbanken/detaljplan/ detaljplaneinstrumentet/vad-ar-detaljplan1/

Boverket. 2016a. Så planeras Sverige. [Thus is Sweden being planned.] Boverket, Karlskrona, Sweden. [online] URL: http:// www.boverket.se/sv/samhallsplanering/sa-planeras-sverige/

Boverket. 2016b. Fördjupningar av och tillägg till översiktsplan. [Elaborations of and supplements to comprehensive plans.] Boverket, Karlskrona, Sweden. [online] URL: http://www. boverket.se/sv/pbl-kunskapsbanken/planering/oversiktsplan/processenfor-oversiktsplanering/fordjupningar-och-tillagg/

Bradshaw, G. A., and J. G. Borchers. 2000. Uncertainty as information: narrowing the science-policy gap. Conservation Ecology 4(1):7. [online] URL: http://www.consecol.org/vol4/iss1/ $\underline{\operatorname{art} 71}$

Colding, J. 2007. 'Ecological land-use complementation' for building resilience in urban ecosystems. Landscape and Urban Planning 81(1-2):46-55. http://dx.doi.org/10.1016/j. landurbplan.2006.10.016

Colding, J. 2011. The role of ecosystem services in contemporary urban planning. Pages 228-237 in J. Niemelä, J. H. Breuste, T. Elmqvist, G. Guntenspergen, P. James, and N. E. McIntyre, editors. Urban ecology: patterns, processes, and applications. Oxford University Press, Oxford, UK. http://dx.doi.org/10.1093/ acprof:oso/9780199563562.003.0028

Delshammar, T. 2015. Ecosystem services in municipal spatial planning. Report 2015:23. Sveriges Lantbruksuniversitet, Alnarp, Sweden. [online] URL: http://pub.epsilon.slu.se/12745/7/ delshammar t 151028.pdf

European Commission (EC). 2011. The EU Biodiversity Strategy to 2020. Publications Office of the European Union, Luxembourg City, Luxembourg. [online] URL: http://ec.europa.eu/environment/ nature/info/pubs/docs/brochures $/ 2020 \% 20$ Biod $\% 20$ brochure $\% 20$ final $\%$ 20lowres.pdf

European Commission (EC). 2015. Towards an EU research and innovation policy agenda for nature-based solutions and re-naturing cities: final report of the Horizon 2020 expert group on 'naturebased solutions and re-naturing cities'. Publications Office of the European Union, Luxembourg City, Luxembourg. [online] URL: https://ec.europa.eu/programmes/horizon2020/en/news/towardseu-research-and-innovation-policy-agenda-nature-based-solutionsre-naturing-cities

Gómez-Baggethun, E., and D. N. Barton. 2013. Classifying and valuing ecosystem services for urban planning. Ecological Economics 86:235-245. http://dx.doi.org/10.1016/j.ecolecon.2012.08.019

Grimm, N. B., S. H. Faeth, N. E. Golubiewski, C. L. Redman, J. Wu, X. Bai, and J. M. Briggs. 2008. Global change and the ecology of cities. Science 319(5864):756-760. http://dx.doi.org/10.1126/ $\underline{\text { science. } 1150195}$ 
Haaland, C., and C. Konijnendijk van den Bosch. 2015. Challenges and strategies for urban green-space planning in cities undergoing densification: a review. Urban Forestry and Urban Greening 14(4):760-771. http://dx.doi.org/10.1016/j.ufug.2015.07.009

Hansen, R., N. Frantzeskaki, T. McPhearson, E. Rall, N. Kabisch, A. Kaczorowska, J.-H. Kain, M. Artmann, and S. Pauleit. 2015. The uptake of the ecosystem services concept in planning discourses of European and American cities. Ecosystem Services 12:228-246. http://dx.doi.org/10.1016/j.ecoser.2014.11.013

Hanson, H., Å. Hesslekrans, J. Lidgren, A. Person, W. Westerberg, M. Ström Remin, K. Görlin, S. Pfeiffer, J. Svännel, and J. Tillgren. 2016. BEST-rapporten (Boverket och Ekosystemtjänsterna) - Får ekosystemtjänster tillräckligt stöd $i$ $P B L$ ? [Do ecosystem services get enough support from the planning and building act?] Malmö stad, Malmö, Sweden. [online] URL: http://www.boverket.se/contentassets/

cc905c6e17a44b0ea26d488bf747b383/far-ekosystemtjanster-tillrackligtstod-i-pbl.pdf

Hauck, J., C. Görg, R. Varjopuro, O. Ratamäki, and K. Jax. 2013. Benefits and limitations of the ecosystem services concept in environmental policy and decision making: some stakeholder perspectives. Environmental Science and Policy 25:13-21. http:// dx.doi.org/10.1016/j.envsci.2012.08.001

Howlett, M., and B. Cashore. 2009. The dependent variable problem in the study of policy change: understanding policy change as a methodological problem. Journal of Comparative Policy Analysis: Research and Practice 11(1):33-46. http://dx.doi. org/10.1080/13876980802648144

Jönsson, K. I., N. Ekelund, C. Wamsler, E. Brink, T. Beery, T. R. Palo, P. Schubert, S. Stålhammar, T. Bramryd, and M. Johansson. 2017. Implementering av ekosystemtjänstbegreppet $i$ kommunal verksamhet. [The implementation of the ecosystem service concept in municipal activities.] Report 6755. Naturvårdsverket, Stockholm, Sweden. [online] URL: https://www.naturvardsverket. se/Documents/publikationer6400/978-91-620-6755-7.pdf?pid=20252

Klimatsamverkan Skåne. 2015. Klimatförändringarnas påverkan på den skånska folkhälsan: en kunskapsöversikt med förslag på åtgärder. [Effects of climate change on Scania's public health.] Second edition. Klimatsamverkan Skåne, Malmö, Sweden. [online] URL: https://utveckling.skane.se/siteassets/

publikationer_dokument/klimatforandringarnas_paverkan_pa_den skanska folkhalsan webb.pdf

Kumar, P., editor. 2010. The economics of ecosystems and biodiversity: ecological and economic foundations. Earthscan, London, UK.

Maczka, K., P. Matczak, A. Pietrzyk-Kaszyńska, M. Rechciński, A. Olszańska, J. Cent, and M. Grodzińska-Jurczak. 2016. Application of the ecosystem services concept in environmental policy-A systematic empirical analysis of national level policy documents in Poland. Ecological Economics 128:169-176. http:// dx.doi.org/10.1016/j.ecolecon.2016.04.023

McKenzie, E., S. Posner, P. Tillmann, J. R. Bernhardt, K. Howard, and A. Rosenthal. 2014. Understanding the use of ecosystem service knowledge in decision making: lessons from international experiences of spatial planning. Environment and Planning $C$ : Government and Policy 32(2):320-340. http://dx.doi.org/10.1068/ c12292j

McKinney, M. L. 2002. Urbanization, biodiversity, and conservation: The impacts of urbanization on native species are poorly studied, but educating a highly urbanized human population about these impacts can greatly improve species conservation in all ecosystems. BioScience 52(10):883-890. http:// dx.doi.org/10.1641/0006-3568(2002)052[0883:UBAC]2.0.CO;2

McPhearson, T., Z. A. Hamstead, and P. Kremer. 2014. Urban ecosystem services for resilience planning and management in New York City. Ambio 43(4):502-515. http://dx.doi.org/10.1007/ s13280-014-0509-8

Miljödepartementet. 2012. Svenska miljömål - preciseringar av miljökvalitetsmålen och en första uppsättning etappmål. [Swedish environmental objectives.] Ds 2012:23. Miljödepartementet, Stockholm, Sweden. [online] URL: http://www.regeringen.se/ contentassets/1941c045c62d446c9ed4392bfaf80130/svenska-miljomal--preciseringar-av-miljokvalitetsmalen-och-en-forsta-uppsattningetappmal-ds-201223

Miljödepartementet. 2013. Synliggöra värdet av ekosystemtjänster: åtgärder för välfärd genom biologisk mångfald och ekosystemtjänster. [Making the value of ecosystem services visible.] SOU 2013:68. Miljödepartementet, Stockholm, Sweden. [online] URL: http:// www.regeringen.se/rattsdokument/statens-offentliga-utredningar/2013/10/ sou-201368/

Millennium Ecosystem Assessment (MEA). 2005a. Ecosystems and human well-being: current state and trends. Island Press, Washington, D.C., USA. [online] URL: https://www. millenniumassessment.org/en/Condition.html

Millennium Ecosystem Assessment (MEA). 2005b. Ecosystems and human well-being: synthesis. Island Press, Washington, D.C., USA.

Nahlik, A. M., M. E. Kentula, M. S. Fennessy, and D. H. Landers. 2012. Where is the consensus? A proposed foundation for moving ecosystem service concepts into practice. Ecological Economics 77:27-35. http://dx.doi.org/10.1016/j.ecolecon.2012.01.001

Naturvårdsverket (NVV). 2015. Miljökvalitetsnormer. [Environmental quality standards.] Naturvårdsverket, Stockholm, Sweden. [online] URL: http://www.naturvardsverket.se/Stod-i-miljoarbetet/ Vagledningar/Miljokvalitetsnormer/

Niemelä, J., S.-R. Saarela, T. Söderman, L. Kopperoinen, V. YliPelkonen, S. Väre, and D. J. Kotze. 2010. Using the ecosystem services approach for better planning and conservation of urban green spaces: a Finland case study. Biodiversity and Conservation 19(11):3225-3243. http://dx.doi.org/10.1007/s10531-010-9888-8

Nin, M., A. Soutullo, L. Rodríguez-Gallego, and E. Di Minin. 2016. Ecosystem services-based land planning for environmental impact avoidance. Ecosystem Services 17:172-184. http://dx.doi. org/10.1016/j.ecoser.2015.12.009

Primmer, E., and E. Furman. 2012. Operationalising ecosystem service approaches for governance: Do measuring, mapping and valuing integrate sector-specific knowledge systems? Ecosystem Services 1(1):85-92. http://dx.doi.org/10.1016/j.ecoser.2012.07.008 
Rall, E. L., N. Kabisch, and R. Hansen. 2015. A comparative exploration of uptake and potential application of ecosystem services in urban planning. Ecosystem Services 16:230-242. http:// dx.doi.org/10.1016/j.ecoser.2015.10.005

Region Skåne. 2006. Att bo och arbeta i Skåne. [Living and working in Scania.] Region Skåne, Malmö, Sweden. [online] URL: https://utveckling.skane.se/publikationer/rapporter-analyseroch-prognoser/att-bo-och-arbete-i-skane/

Region Skåne. 2012. Grönstruktur i Skåne. [Green structure in Scania.] Region Skåne, Malmö, Sweden. [online] URL: https:// utveckling.skane.se/publikationer/rapporter-analyser-och-prognoser/ temapm---gronstruktur-i-skane/

Rydell, B., and K. Lundström. 2013. Erosion vid kuster och vattendrag: probleminventering och kunskapsbehov. [Erosion along coasts and water streams.] SGI Publication 11. Statens geotekniska institut, Linköping, Sweden. [online] URL: http:// www.swedgeo.se/globalassets/publikationer/sgi-publikation/sgi-p11. pdf

Schröter, M., E. H. van der Zanden, A. P. E. van Oudenhoven, R. P. Remme, H. M. Serna-Chavez, R. S. de Groot, and P. Opdam. 2014. Ecosystem services as a contested concept: a synthesis of critique and counter-arguments. Conservation Letters 7 (6):514-523. http://dx.doi.org/10.1111/conl.12091

Sitas, N., H. E. Prozesky, K. J. Esler, and B. Reyers. 2014. Exploring the gap between ecosystem service research and management in development planning. Sustainability 6 (6):3802-3824. http://dx.doi.org/10.3390/su6063802

Statistiska Centralbyrån (SCB). 2016. Folkmängd i riket, län och kommuner 31 december 2015 och befolkningsförändringar 2015. [Population in the nation, counties and municipalities $31 \mathrm{dec} 2014$ and population changes 2015.] Statistics Sweden, Stockholm, Sweden. [online] URL: http://www.scb.se/hitta-statistik/statistikefter-amne/befolkning/befolkningens-sammansattning/befolkningsstatistik/ pong/tabell-och-diagram/helarsstatistik--kommun-lan-och-riket/ folkmangd-i-riket-lan-och-kommuner-31-december-2015-ochbefolkningsforandringar-2015/

Storbjörk, S. 2004. Att prioritera miljöfrågor? Kommunpolitikerna och det lokala miljöarbetets villkor. (Kommunen och territoriet 5). Kungliga Tekniska Högskolan Research Report 04-015. KTH Royal Institute of Technology, Stockholm, Sweden.

Sveriges Kommuner och Landsting (SKL). 2012. Lokala miljömål och nationellt stöd: resultat av SKL: s enkät och djupintervjuer 2011 och 2012. [Local environmental objectives and national support.] Sveriges Kommuner och Landsting, Stockholm, Sweden. [online] URL: http://webbutik.skl.se/sv/artiklar/lokala-miljomal-och-nationellstod-resultat-av-skls-enkat-och-djupintervjuer-2011-och-2012.html

The Economics of Ecosystems and Biodiversity (TEEB). 2011. TEEB manual for cities: ecosystem services in urban management. TEEB, Geneva, Switzerland.

United Nations. 1992. Convention on biological diversity. Secretariat of the Convention on Biological Diversity, Montreal, Canada. [online] URL: https://www.cbd.int/convention/text/ default.shtml
Wamsler, C., C. Luederitz, and E. Brink. 2014. Local levers for change: mainstreaming ecosystem-based adaptation into municipal planning to foster sustainability transitions. Global Environmental Change 29:189-201. http://dx.doi.org/10.1016/j. gloenvcha.2014.09.008

Wamsler, C., L. Niven, T. H. Beery, T. Bramryd, N. Ekelund, K. I. Jönsson, A. Osmani, T. Palo, and S. Stålhammar. 2016. Operationalizing ecosystem-based adaptation: harnessing ecosystem services to buffer communities against climate change. Ecology and Society 21(1):31. http://dx.doi.org/10.5751/ ES-08266-210131

Wilkinson, C., T. Saarne, G. D. Peterson, and J. Colding. 2013. Strategic spatial planning and the ecosystem services concept an historical exploration. Ecology and Society 18(1):37. http://dx. doi.org/10.5751/ES-05368-180137

Wissen Hayek, U., M. Teich, T. M. Klein, and A. Grêt-Regamey. 2016. Bringing ecosystem services indicators into spatial planning practice: lessons from collaborative development of a web-based visualization platform. Ecological Indicators 61(1):90-99. http:// dx.doi.org/10.1016/j.ecolind.2015.03.035

Woodruff, S. C., and T. K. BenDor. 2016. Ecosystem services in urban planning: comparative paradigms and guidelines for high quality plans. Landscape and Urban Planning 152:90-100. http:// dx.doi.org/10.1016/j.landurbplan.2016.04.003 


\section{Appendix A1}

Table A1.1. Population numbers and green space per capita. Population size and changes between the years 2014-2015 for each of the studied municipalities (SCB 2015, SCB 2016) as well as the proportion of green and blue spaces within the urban centres (SCB 2010).

\begin{tabular}{lccc}
\hline \hline Municipality & $\begin{array}{l}\mathbf{N}^{\circ} \text { of inhabitants } \\
\mathbf{3 1} \mathbf{~ d e c ~} \mathbf{2 0 1 5}\end{array}$ & $\begin{array}{l}\text { Increase from 31 } \\
\text { dec 2014 (\%) }\end{array}$ & $\begin{array}{l}\text { Green + blue } \\
\text { space in 2005 (\%) }\end{array}$ \\
\hline Small & & & \\
Staffanstorp & 23119 & 0.54 & 6 \\
Burlöv & 17430 & 1.27 & No data \\
Höganäs & 25610 & 1.23 & 10 \\
Large & 322574 & 1.40 & 16 \\
Malmö & 116834 & 0.74 & 8 \\
Lund & 137909 & 1.89 & 20 \\
Helsingborg & & & \\
\hline
\end{tabular}




\section{Appendix 2.}

Table A2.1. Levels of detail for individual ecosystem service (ES). How in-depth each ES was addressed in the documents: $\mathrm{E}=$ elaborate with linkage to targets, $\mathrm{A}=$ acknowledged, $\mathrm{P}=$ problem mentioned but not linked to ecosystem services.

\begin{tabular}{|c|c|c|c|c|c|c|c|c|c|c|c|}
\hline \multirow{3}{*}{ Ecosystem services } & \multicolumn{11}{|c|}{ Municipalities } \\
\hline & \multicolumn{2}{|c|}{ Staffanstorp } & \multicolumn{3}{|l|}{ Burlöv } & \multicolumn{6}{|c|}{ Höganäs } \\
\hline & Sta_1 & Sta_2 & Bur_1 & Bur_2 & Bur_3 & Hög_1 & Hög_2 & Hög_3 & Hög_4 & Hög_5 & Hög_6 \\
\hline \multicolumn{12}{|l|}{ Regulating } \\
\hline Local climate regulation & & & E & & & & A & & & & \\
\hline Air quality regulation & $\mathrm{P}$ & & E & A & & $\mathrm{P}$ & $\mathrm{P}$ & & & & \\
\hline \multicolumn{12}{|l|}{ Carbon sequestration and storage } \\
\hline Water regulation & E & E & E & $\mathrm{E}$ & E & A & $\mathrm{E}$ & & & $\mathrm{E}$ & \\
\hline Moderation of extreme events & E & E & E & A & E & & E & & & $\mathrm{P}$ & \\
\hline Wastewater treatment & E & & $\mathrm{E}$ & $\mathrm{E}$ & $\mathrm{E}$ & $\mathrm{A}$ & E & A & & & \\
\hline Erosion prevention & & & $\mathrm{P}$ & $\mathrm{P}$ & $\mathrm{P}$ & $\mathrm{P}$ & A & & & $\mathrm{E}$ & \\
\hline Pollination & & & A & $\mathrm{A}$ & & & & $\mathrm{A}$ & & & \\
\hline \multicolumn{12}{|l|}{ Biological pest control } \\
\hline \multicolumn{12}{|l|}{ Supporting } \\
\hline Habitat for species and biodiversity & E & $\mathrm{E}$ & $\mathrm{E}$ & $\mathrm{E}$ & E & $\mathrm{E}$ & $\mathrm{A}$ & $\mathrm{A}$ & E & $\mathrm{P}$ & \\
\hline Nutrient cycling & & & A & A & & & A & & & & \\
\hline \multicolumn{12}{|l|}{ Water cycling } \\
\hline $\begin{array}{l}\text { Photosynthesis and primary } \\
\text { production } \\
\text { Soil formation }\end{array}$ & & & & & & & & A & & & \\
\hline \multicolumn{12}{|l|}{ Provisioning } \\
\hline Food & $\mathrm{E}$ & $\mathrm{P}$ & $\mathrm{E}$ & $\mathrm{E}$ & $\mathrm{P}$ & $\mathrm{E}$ & $\mathrm{E}$ & $\mathrm{P}$ & $\mathrm{P}$ & $\mathrm{P}$ & \\
\hline Fresh water & A & & $\mathrm{E}$ & $\mathrm{E}$ & A & $\mathrm{E}$ & & & $\mathrm{A}$ & $\mathrm{A}$ & \\
\hline Raw materials & $\mathrm{E}$ & & A & A & & & & A & & & \\
\hline \multicolumn{12}{|l|}{ Natural medicinal resources } \\
\hline \multicolumn{12}{|l|}{ Cultural } \\
\hline $\begin{array}{l}\text { Recreation and mental and } \\
\text { physical health }\end{array}$ & E & $\mathrm{E}$ & $\mathrm{E}$ & $\mathrm{E}$ & E & $\mathrm{E}$ & $\mathrm{E}$ & & & A & A \\
\hline Tourism & A & & & & & A & $\mathrm{E}$ & & & A & \\
\hline $\begin{array}{l}\text { Aesthetic appreciation and } \\
\text { inspiration }\end{array}$ & & & E & A & $\mathrm{E}$ & $\mathrm{E}$ & A & & & & \\
\hline $\begin{array}{l}\text { Spiritual and religious values and } \\
\text { sense of place }\end{array}$ & E & A & $\mathrm{E}$ & A & & A & & & & & \\
\hline Educational values & $\mathrm{P}$ & $\mathrm{A}$ & E & & & & & & & & \\
\hline
\end{tabular}




\section{Malmö}

Mal_1 Mal_2 Mal_3 Mal_4 Mal_5 Mal_6 Mal_7 $\quad$ Mal_8 Mal_9 Mal_10

Regulating

Local climate regulation

Air quality regulation

Carbon sequestration and storage

Water regulation

Moderation of extreme events

Wastewater treatment

Erosion prevention

Pollination

Biological pest control

\section{Supporting}

Habitat for species and biodiversity

Nutrient cycling

Water cycling

Photosynthesis and primary

production

Soil formation

Provisioning

Food

Fresh water

Raw materials

Natural medicinal resources

Cultural

Recreation and mental and physical health

Tourism

Aesthetic appreciation and

inspiration

Spiritual and religious values and sense of place

Educational values

E $A$ A

A

A

A

E

E

A

E

A

P

A E

A $\quad$ E

A

E

E A

E

A

A

A

A

A

$\begin{array}{ll}\text { A } & \text { E } \\ & \text { P } \\ & \text { E }\end{array}$

$\begin{array}{lll}\text { E } & \text { E } & \text { E } \\ P & & E \\ & & \text { E }\end{array}$

$\begin{array}{llllllllll}\text { E } & \text { A } & \text { E } & \text { A } & \text { E } & \text { P } & \text { E } & \text { E } & \text { A } & \text { E } \\ & & \text { A } & & & \text { E } & \text { E } & & \\ \text { E } & \text { A } & \text { A } & & & & & \text { A } & \text { A } \\ & \text { A } & \text { A } & & & & & & \text { A } & \\ & \text { A } & \text { E } & \text { P } & & & \text { E } & \text { E }\end{array}$




\section{Lund}

Lun_1 Lun_2 Lun_3 Lun_4 Lun_5 Lun_6 Lun_7 Lun_8 $\quad$ Lun_9 Lun_10

\section{Regulating}

\begin{tabular}{|c|c|c|c|c|c|c|c|c|c|}
\hline Local climate regulation & E & A & & $\mathrm{E}$ & A & E & & & $\mathrm{A}$ \\
\hline Air quality regulation & E & A & & $\mathrm{E}$ & A & E & & & $\mathrm{A}$ \\
\hline \multicolumn{9}{|l|}{$\begin{array}{l}\text { Carbon sequestration and } \\
\text { storage }\end{array}$} & \\
\hline Water regulation & E & $\mathrm{E}$ & $\mathrm{E}$ & $\mathrm{E}$ & A & E & $\mathrm{E}$ & $\mathrm{E}$ & \\
\hline $\begin{array}{l}\text { Moderation of extreme } \\
\text { events }\end{array}$ & $P$ & & & & $\mathrm{P}$ & A & & $\mathrm{E}$ & \\
\hline Wastewater treatment & E & $\mathrm{P}$ & & A & A & E & E & $\mathrm{E}$ & \\
\hline Erosion prevention & $P$ & & & & A & A & & & \\
\hline Pollination & & & & A & A & & & & \\
\hline Biological pest control & & & & & A & & & & \\
\hline \multicolumn{9}{|l|}{ Supporting } & \\
\hline $\begin{array}{l}\text { Habitat for species and } \\
\text { biodiversity }\end{array}$ & E & $\mathrm{E}$ & & $\mathrm{E}$ & E & E & E & $\mathrm{E}$ & $\mathrm{E}$ \\
\hline Nutrient cycling & E & E & & & E & & & & \\
\hline Water cycling & & & & & & & & A & \\
\hline $\begin{array}{l}\text { Photosynthesis and } \\
\text { primary production }\end{array}$ & & & & & A & & & & \\
\hline Soil formation & & & & & A & & & & \\
\hline
\end{tabular}

\section{Provisioning}

Food
Fresh water
Raw materials
Natural medicinal
resources
Cultural
Recreation and mental and
physical health
Tourism
Aesthetic appreciation and
inspiration
Spiritual and religious
values and sense of place
Educational values

$\begin{array}{lllllll}\text { E } & \text { E } & \text { E } & \text { A } & \text { E } & \text { E } & \text { P } \\ \text { E } & \text { E } & \text { E } & \text { A } & & & \\ \text { E } & \text { A } & & \text { A } & \text { A } & & \end{array}$

Educational values

$\begin{array}{llll}\text { E } & \text { E } & \text { E } & \text { E } \\ \text { E } & & \\ \text { A } & \text { E } & \\ \text { E } & \\ \text { A } & \text { A }\end{array}$

$\begin{array}{llllll}\text { A } & \text { E } & \text { E } & \text { E } & \text { A } & \text { P } \\ & \text { A } & & & & \\ \text { A } & \text { E } & & \text { E } & \text { E } & \\ & \text { A } & & & & \\ & \text { E } & \text { E } & & \text { P }\end{array}$




\section{Helsingborg}

Hel_1 Hel_2 Hel_3 Hel_4 Hel_5 Hel_6 Hel_7 Hel_8

\begin{tabular}{|c|c|c|c|c|c|c|c|c|}
\hline Local climate regulation & A & E & $\mathrm{E}$ & $\mathrm{E}$ & & \multicolumn{3}{|c|}{$\mathrm{E}$} \\
\hline Air quality regulation & E & $\mathrm{E}$ & $\mathrm{E}$ & $\mathrm{E}$ & E & & & \\
\hline $\begin{array}{l}\text { Carbon sequestration and } \\
\text { storage }\end{array}$ & A & & & $\mathrm{E}$ & & & $\mathrm{E}$ & \\
\hline Water regulation & $\mathrm{E}$ & E & E & E & E & & $\mathrm{E}$ & $\mathrm{E}$ \\
\hline Moderation of extreme events & $\mathrm{E}$ & E & & E & E & & $\mathrm{E}$ & $\mathrm{E}$ \\
\hline Wastewater treatment & E & E & A & E & E & & $\mathrm{E}$ & $\mathrm{E}$ \\
\hline Erosion prevention & & A & A & A & & & $\mathrm{E}$ & \\
\hline Pollination & & & A & $\mathrm{E}$ & & & & \\
\hline Biological pest control & & & A & A & & & $\mathrm{P}$ & \\
\hline \multicolumn{9}{|l|}{ Supporting } \\
\hline $\begin{array}{l}\text { Habitat for species and } \\
\text { biodiversity }\end{array}$ & $\mathrm{E}$ & $\mathrm{E}$ & E & $\mathrm{E}$ & $\mathrm{E}$ & $\mathrm{E}$ & $\mathrm{E}$ & $\mathrm{E}$ \\
\hline Nutrient cycling & & & & A & & & & \\
\hline Water cycling & & & & A & & & & \\
\hline \multicolumn{9}{|l|}{$\begin{array}{l}\text { Photosynthesis and primary } \\
\text { production }\end{array}$} \\
\hline Soil formation & & & A & & & & & \\
\hline \multicolumn{9}{|l|}{ Provisioning } \\
\hline Food & $\mathrm{E}$ & $P$ & A & A & & $P$ & A & \\
\hline Fresh water & E & & & A & & & A & \\
\hline Raw materials & & & & A & & & $\mathrm{E}$ & \\
\hline Natural medicinal resources & & & & A & & & & \\
\hline \multicolumn{9}{|l|}{ Cultural } \\
\hline $\begin{array}{l}\text { Recreation and mental and } \\
\text { physical health }\end{array}$ & E & $\mathrm{E}$ & E & $\mathrm{E}$ & E & $\mathrm{E}$ & $\mathrm{E}$ & $\mathrm{E}$ \\
\hline Tourism & E & & & E & & & & \\
\hline $\begin{array}{l}\text { Aesthetic appreciation and } \\
\text { inspiration }\end{array}$ & E & & & E & & & & A \\
\hline $\begin{array}{l}\text { Spiritual and religious values and } \\
\text { sense of place }\end{array}$ & A & & E & A & E & $\mathrm{E}$ & & \\
\hline Educational values & A & $\mathrm{E}$ & $\mathrm{E}$ & $\mathrm{E}$ & & $\mathrm{E}$ & & A \\
\hline
\end{tabular}

